\title{
The Roles of Nutritional Knowledge on Culinary Students in Pandemic Covid-19
}

\author{
Mahdiyah $^{1 *}$, Mutiara Dahlia ${ }^{1}$, S A Hakim ${ }^{1}$, Kasyifaturrahmah $^{1}$, Fildzah Rudyah \\ Putri $^{2}$
}

${ }^{I}$ Faculty of Technology State University of Jakarta, Indonesia

${ }^{2}$ Faculty of Education Psychology State University of Jakarta, Indonesia

${ }^{*}$ Corresponding author. Email: mahdiyah.unj@gmail.com

\begin{abstract}
The world was shocked by the outbreak of the Covid-19 Virus, with the spread of almost all countries in the world starting in early 2020, followed by the announcement of the status of a Global Pandemic by the World Health Organization (WHO). The role of nutritional knowledge possessed further contributes to the fulfilment of nutrition to maintain immunity during a pandemic situation, so as to avoid infection with the Corona Virus. This study was conducted to determine the role of nutritional knowledge and its application to Culinary students compared to other study program students, at the State University of Jakarta. Culinary students in their learning receive lecture materials related to knowledge of Nutrition, Food Science, and Sanitation Hygiene, which are not given to students of other study programs at the State University of Jakarta. Research on 256 students was carried out using the Independent t-test, it was proven that the Knowledge and Application of Nutrition of Culinary students was significantly different and better, compared to students of other study program. The results of this study provide important information for observers in the fields of food, nutrition and health education, especially the Culinary Study program in assessing the role of learning quality according to the curriculum delivered on campus. This research of course also plays a very important role as a benchmark for lecturers to assess whether or not the targeted learning objectives have been delivered. It also reminds us how important it is to always give learning seriously and correctly, so that it is useful for students' lives in any condition.
\end{abstract}

\section{Keywords: Covid-19, Nutritional Knowledge, Culinary Students}

\section{INTRODUCTION}

In December 2019, a mysterious case of pneumonia was first reported in Wuhan, Hubei province. But not until a month later, this virus has spread in various other countries besides China, Thailand, Japan and South Korea. Furthermore, this virus is called Covid19 which stands for Corona (CO) Virus (VI) Disease (D) [13].

The World Health Organization [14] says that this corona virus causes a person to experience mild flu to more severe respiratory infections such as MERS$\mathrm{CoV}$ and SARS-CoV. The virus that causes a person to suffer from COVID-19 can be transmitted through droplets (splashes of saliva) produced when someone infected with Covid-19 coughs, sneezes or exhales [14]. Other people whose air contains the Covid-19 virus can also be infected.
As of July 2021, it is known that $196,741,728$ people in the world have contracted Covid-19 [4]. The development of cases in Indonesia is also not too different from the conditions of global cases. From June to July, there was a high increase in cases in Indonesia. We can see news about hospitals being full and oxygen cylinder crisis on television and social media every day.

The vigilance of the outbreak during this pandemic, which initially only had a crisis impact on the health sector, has now shifted to a multi-crisis, including those targeting social and economic life. The COVID-19 outbreak has the potential to damage fragile health systems, especially in low-income countries, namely survival, health, and safety outcomes.

Various efforts have been made by the Indonesian government to reduce the level of transmission of 
COVID-19, such as large-scale social restrictions, the obligation to use masks, washing hands, temperature checks, physical distancing, working and schooling from home, and campaigns for fulfilling nutritious food.

Although currently a vaccine to prevent contracting the Covid-19 virus has been found and distributed to the wider community. However, self-prevention efforts still need to be carried out, such as implementing clean and healthy living behaviours, and consuming nutritious food. This prevention effort continues to be conveyed by the government and other institutions in the context of preventing the spread of Covid-19.

The Ministry of Health of the Republic of Indonesia together with Gerakan Kesehatan Masyarakat (Germas) recommends consuming balanced nutrition as one of the steps taken by the community to somewhat successfully prevent the transmission of Covid-19. During a pandemic like today, the body needs a balanced nutritional intake to boost the immune system against bacteria and viruses that cause disease [5].

Fulfilment of balanced nutritional consumption during this pandemic is highly recommended, but with various limitations such as the economy, it is hoped that the community will have adequate mastery of nutritional knowledge. The nutritional knowledge possessed, will be very helpful in deciding the choice of nutritious food but with economic value and still affordable. Nutritious food does not mean synonymous with expensive food.

Nutrition science discusses the nutritional content of food, the metabolic processes that affect it, and the consequences of a lack of nutrients in the body [1]. Nutrition has an important role in influencing a person's level of health. One of the nutritional conditions of a person is influenced by nutritional knowledge and its application.

Knowledge can be obtained both formally and informally, which in turn can shape a person's attitude. Good nutritional knowledge will affect a person's actions in meeting their daily nutritional needs. This is of course very important, especially during a pandemic. Proper nutritional knowledge which further contributes to the fulfilment of nutrition must still be considered properly, to maintain immunity so as to avoid infection with the Covid-19 virus.

Good nutritional knowledge is believed to influence a person's consumption patterns in meeting their nutritional needs. Someone with a high level of nutritional knowledge is expected to pay more attention to their food consumption, both in terms of quality and type [10]. Meanwhile, individuals with low nutritional knowledge tend to choose foods that are attractive to their five senses, without considering the nutritional value of these foods.
Based on research conducted by Selaindoong et al., [11], it is known that students who receive special education on nutrition have a good level of nutritional knowledge. The results of this study are in line with previous research conducted on students at the Jakarta II Health Polytechnic [12]. In this study, it was found that 93\% of students had a good level of nutritional knowledge. Meanwhile, Florence [3] conducted a similar study on ITB School of Business and Management students who had never received any nutrition education at all, and it was found that only $8.8 \%$ of students had a good level of nutritional knowledge. Based on some of the results of these studies, the researchers assumed that the level of nutritional knowledge of these students was different between students who received education in the field of nutrition and those who did not receive education in the field of nutrition.

Therefore, this research wants to see the role of the Curriculum of Culinary students on their knowledge of nutrition. This culinary student knowledge score will be compared with the nutritional knowledge score owned by students other than Culinary Program Study.

\section{METHODS}

The research method used in this case is an independent t-test analysis, comparing the score of nutritional knowledge and its application to culinary students compared to other study program students, at the State University of Jakarta. Culinary students in their learning receive educational materials related to Nutrition, Science, and Sanitation Hygiene, which are not given to students in other study programs. The research was conducted by using 256 students as respondents, consisting of students from the Culinary Study Program and other students other than the Culinary Study Program.

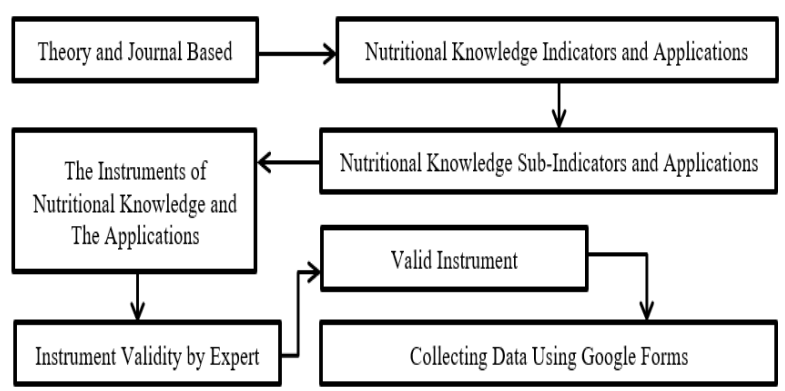

Figure 1 Research Process

Diagram 1 above shows the research process carried out in this study. The research process begins with looking for theories and journals. After finding theories 
and journals related to the phenomenon to be studied, researchers began to look for indicators of nutritional knowledge and their applications. Based on the indicators obtained, the researchers then compiled sub-indicators of knowledge and application of nutrition based on theory. After all indicators and sub-indicators have been compiled, the researcher begins to develop instruments for knowledge and application of nutrition. The instruments that have been made are then validated by experts. After obtaining a valid instrument, the research continued by collecting research data using google form.

This research analysis method begins with the analysis requirements test phase, namely the Normality Test, to ensure that the data used will meet the requirements for analysis using the Independent T-Test. The results of the analysis prove that the nutrition knowledge data used is normally distributed.
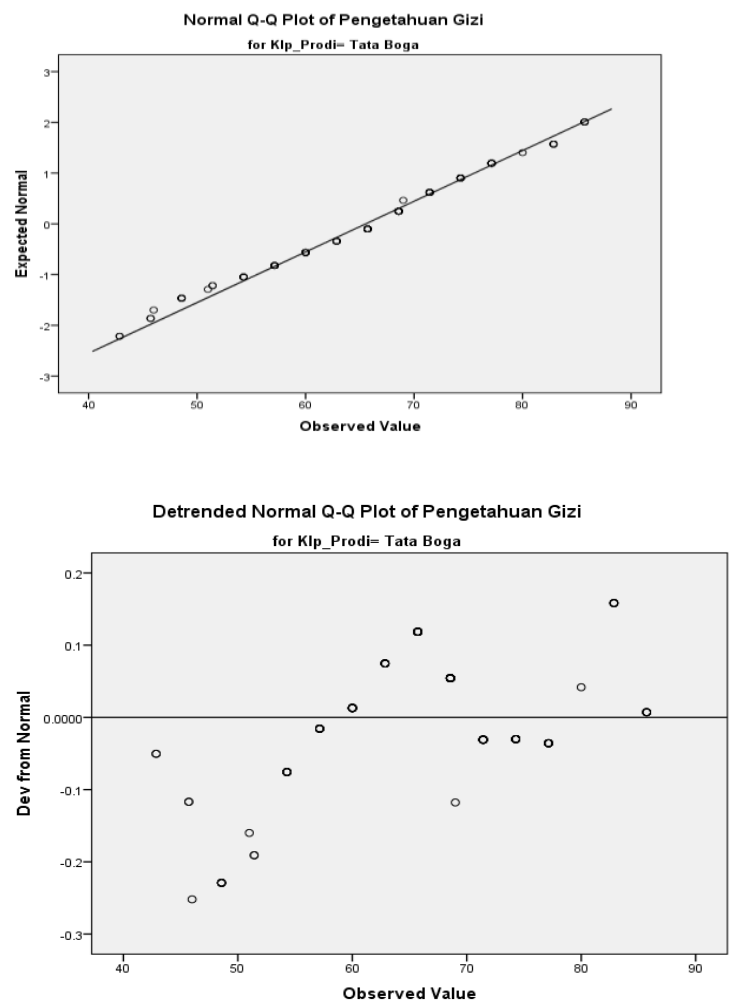
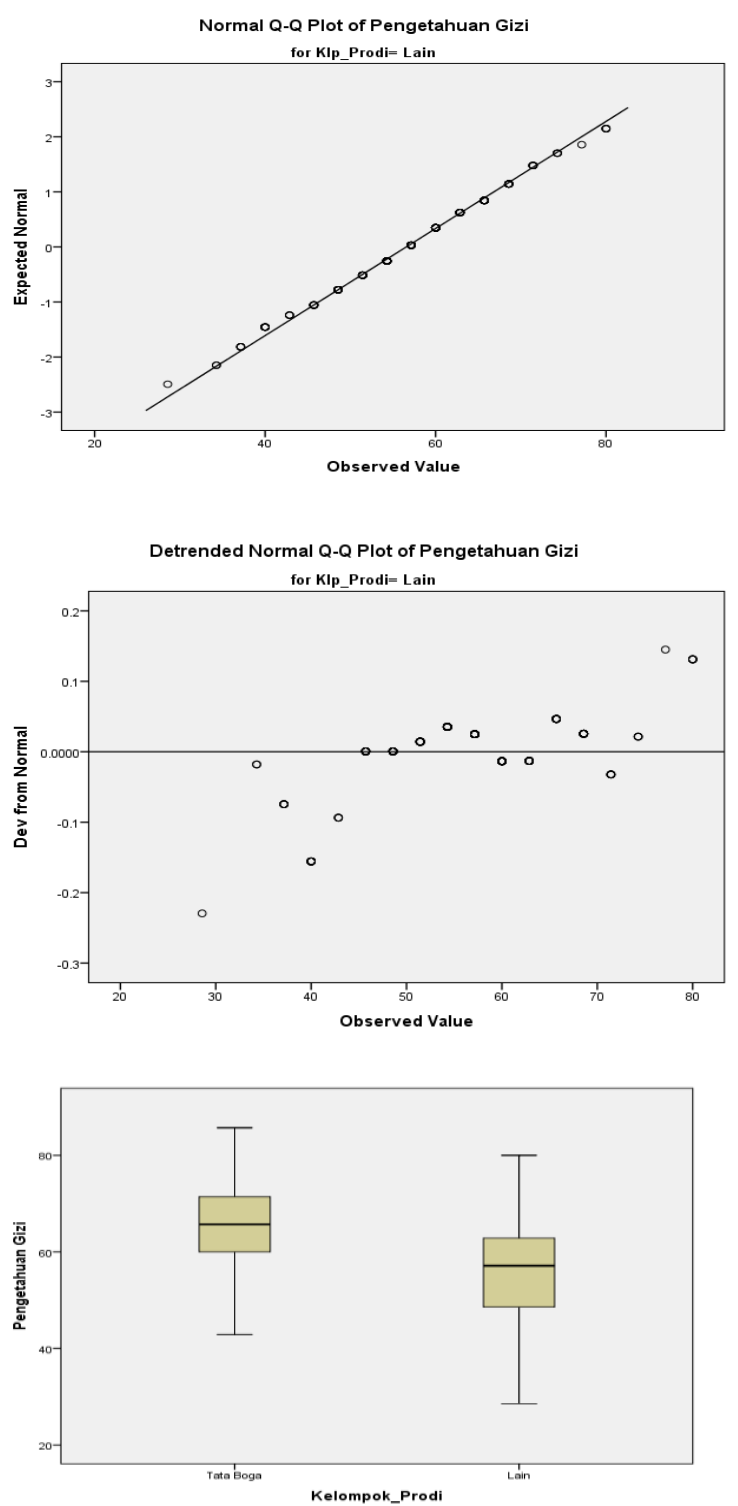

Figure 2 Normality Test

\section{RESULTS AND DISCUSSION}

The respondents used in this study were UNJ students consisting of 111 students of the Culinary Study Program and 157 other Study Program students outside of the Culinary Study Program students.

The results of the comparison test between students' nutritional knowledge, which they understood and applied during this pandemic, were carried out using t-test statistical hypothesis analysis. The analysis of the t-test used is an independent t-test, where the nutritional knowledge data of each culinary student and non-culinary student is independent $[6,15]$. 
Table 1. Descriptive

\begin{tabular}{|l|l|c|c|c|c|}
\hline \multicolumn{5}{|c|}{ Group Statistics } \\
\hline & Study Program & $\mathrm{N}$ & Mean & Std. Deviation & Std. Error Mean \\
\hline $\begin{array}{l}\text { Nutritional } \\
\text { Knowledge }\end{array}$ & Culinary Students & 111 & 65.54 & 10.013 & 0.950 \\
\cline { 2 - 6 } & Others & 157 & 56.56 & 10.280 & 0.820 \\
\hline
\end{tabular}

Table 2. Independent Samples Test

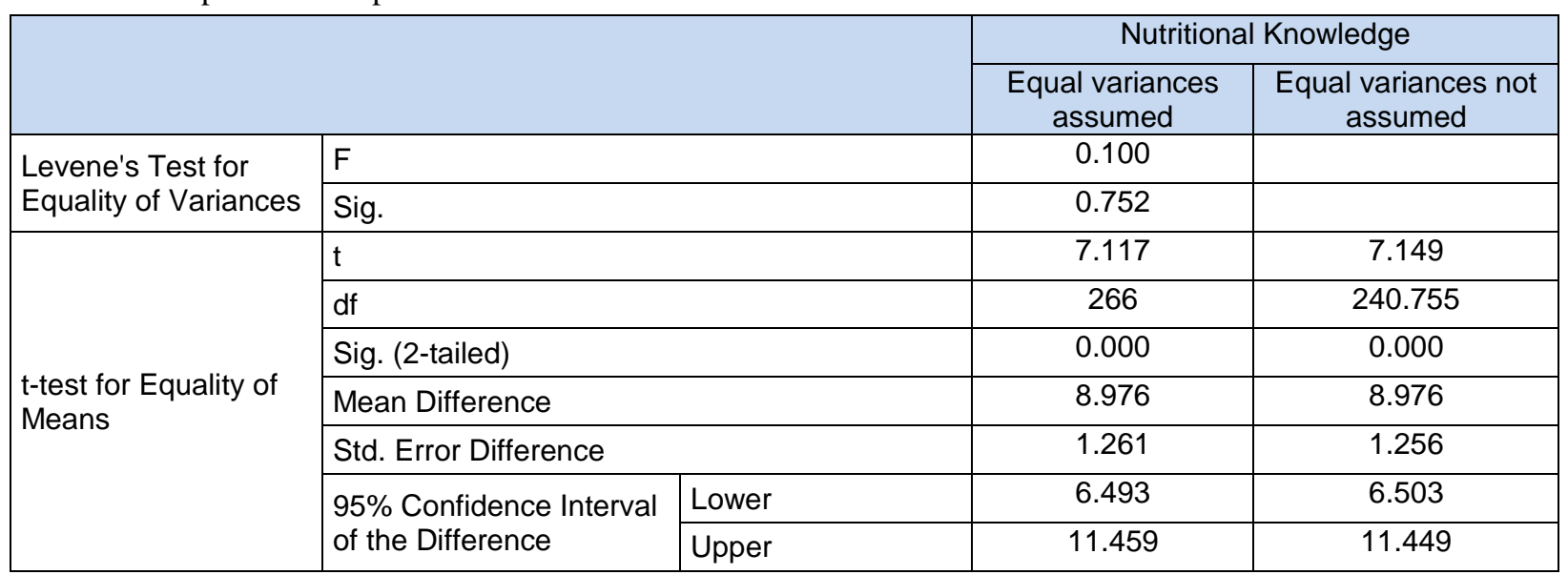

The results of the t-test hypothesis prove that there is a significant difference (Sig. 2-tailed: 0.000) in the nutritional knowledge score between the student group of the Culinary Study Program compared to the student group of the study program other than the Culinary Study Program. The mean score of nutritional knowledge of the Culinary Study Program student group (65.54) was proven to be higher or better than the mean score of nutrition knowledge (56.56) in the student study program group other than the Culinary Study Program.

A person's nutritional knowledge can be influenced by various things, one of which is education about nutrition $[8,9]$. If we look at the results of the research above, it is known that culinary students who receive an education curriculum on nutrition have higher nutritional knowledge than students who have never received a course on nutrition.

The results of this study are in line with previous research conducted by Bening [2], where students majoring in nutrition have high knowledge of nutrition, which is $90 \%$. Meanwhile, law students who have never received a course on nutrition only have a moderate level of nutritional knowledge, which is $62 \%$.
The difference in nutritional knowledge in the two sample groups is strongly influenced by the educational background of the sample. Culinary students certainly have better knowledge, because they get nutrition courses and all the material studied during the study period is not far from food and nutrition problems. Meanwhile, the non-culinary students who were the sample in this study never received formal courses on nutrition.

Knowledge of nutrition can be interpreted as knowledge of nutritional science, such as nutrients and their sources in food, what types of food are safe for consumption to avoid disease, proper food processing steps to maintain nutrients in food [7]. Therefore, this nutritional knowledge is very important for someone to have, especially during the covid-19 pandemic.

With the high level of nutritional knowledge of a person, it is hoped that the person can have a higher awareness in meeting their daily nutritional needs. Furthermore, fulfilling these nutritional needs can make a person have a higher immunity, so that they are not infected with COVID-19 and are able to break the chain of transmission of Covid-19

\section{CONCLUSION}

Based on the research results obtained, it is known that the culinary students have a higher level of knowledge than non-Culinary students. The high level of knowledge of culinary students is strongly influenced by the educational curriculum obtained by culinary students. 
Various courses related to nutrition and food processing have a very high role in the nutritional knowledge level of culinary students. Henceforth, this research still needs to be refined by adding an analysis of other variables, such as consumption patterns in students.

\section{ACKNOWLEDGMENT}

The researchers would like to thank the students who were involved in this research. In addition, the researchers would also like to thank the State University of Jakarta which has helped fund this research.

\section{REFERENCES}

[1] Adriani M, Wirjatmadi B 2016 Pengantar Gizi Masyarakat (Jakarta: Kencana)

[2] Bening S, Margawati A 2014 Perbedaan Pengetahuan Gizi, Body Image, Asupan Energi Dan

Status Gizi Pada Mahasiswi Gizi Dan Non Gizi Universitas Diponegoro (Doctoral dissertation, Diponegoro University)

[3] Florence AG 2017 Hubungan Pengetahuan Gizi dan Pola Konsumsi dengan Status Gizi pada Mahasiswa TPB Sekolah Bisnis dan Manajemen Institut Teknologi Bandung (Skripsi Universitas Pasundan, Bandung)

[4] Google News 2021 https://news.google.com/covid19/map?hl=enID\&gl=ID\&ceid=ID\%3Aen

[5] Kementerian Kesehatan RI 2020 Panduan Gizi Seimbang Pada Masa Pandemi COVID-19 (Jakarta: Kemenkes RI)

[6] Mahdiyah 2014 Statistik Pendidikan (PT Remaja Rosdakarya, Bandung)

[7] Notoatmodjo S 2003 Pendidikan dan Perilaku Kesehatan (Jakarta: Rineka Cipta)

[8] Nurmalia Syahriri, Abdul Razak Thaha, Nurhaedar Jafar 2013 Pengetahuan Gizi, Body Image,

Dan Status Gizi Remaja Islam Athirah Kota Makassar Tahun 2013 (Skripsi Program Studi Ilmu Gizi Fakultas Kesehatan Masyarakat Universitas Hasanuddin)

[9] Ruka Samakaki, Kenji Toyama, Rie Amamoto, Chuan-Jun Liu, Naotaka Shinfuku 2005

Nutritional Knowledge, Food Habits and Health Attitude of Chinese University Students-A Cross Sectional Study Nutrition Journal

[10] Sediaoetama AD 200 Ilmu Gizi untuk Mahasiswa dan Profesi Jilid I (Dian Rakyat, Jakarta)

[11] Selaindoong S J, Amisi M D, Kalesaran A F C 2020 Gambaran Pengetahuan Gizi Mahasiswa
Semester IV Fakultas Kesehatan Masyarakat Universitas Sam Ratulangi Saat Pembatasan Sosial Masa Pandemi Covid-19 Jurnal Kesmas

[12] Utami AP 2019 Gambaran Status Gizi, Tingkat Pengetahuan Gizi dan Aktivitas Fisik Mahasiswa di Jurusan Teknik Elektromedik Politeknik Kesehatan Jakarta II, Jakarta Selatan (Tugas Akhir Politeknik Kesehatan Kemenkes Jakarta II)

[13] WHO names novel coronavirus as 'COVID-19' 2020 https://www.channelnewsasia.com/news/world/wuhan-virus-coronavirus-who-new-name-12424116

[14] WHO 2020 Coronavirus Disease (Covid-19) World Health Organization

[15] Wibawa B, Mahdiyah, Afgani 2014 Metodologi Penelitian Pendidikan (Tangerang Selatan: Penerbit Universitas Terbuka) 